Original Research Paper

\title{
The Visceral Organ, Gastrointestinal Tract and Blood Characteristics in Pegagan Ducks Fed Ration Fermented by Tape Yeast with Different Moisture Content
}

\author{
${ }^{1}$ Fitra Yosi, ${ }^{1}$ Sofia Sandi and ${ }^{2}$ Miksusanti \\ ${ }^{I}$ Department of Animal Science, Faculty of Agriculture, University of Sriwijaya, South Sumatera, Indonesia \\ ${ }^{2}$ Department of Chemistry, Faculty of Mathematics and Natural Sciences, \\ University of Sriwijaya, South Sumatera, Indonesia
}

Article history

Received: 10-02-2017

Revised: 19-05-2017

Accepted: 18-08-2017

Corresponding Author:

Fitra Yosi

Department of Animal Science,

Faculty of Agriculture,

University of Sriwijaya, South

Sumatera, Indonesia

E-mail: fitrayosi@unsri.ac.id

\begin{abstract}
The purpose of this study was to assess the effect of administration diet containing locally sourced materials fermented by tape yeast with different moisture content on the weight of the visceral organs, gastrointestinal tract and blood chemistry and profile of Pegagan ducks. As many as 200 Pegagan ducks aged 3 days were kept for 6 weeks in colony cages. This study used a completely randomized design that consisted of 5 treatments and 4 replicates. The treatments tested were symbolized as P1, P2, P3, P4 and P5 based on the level of moisture content used in the fermentation process of ration, namely control, 40, 50, 60 and $70 \%$. Data were analyzed by analysis of variance continued by Duncan's multiple range test at $5 \%$. The weight of gizzard, pancreas, crop-oesophagus, proventriculus, the total of small intestine and ceca were significantly $(p<0.05)$ affected by treatment, but did not significantly affect $(p>0.05)$ on the weight of bile, liver, spleen, heart, duodenum, jejunum, ileum and rectum. Furthermore, blood cholesterol, triglyceride and LDL of Pegagan ducks were significantly $(p>0.05)$ different. It can be concluded that the fermentation process of locally sourced ration using a moisture content of $50 \%$ gives the optimal result on the weight of visceral organ, gastrointestinal tract and also blood chemistry and profile of Pegagan ducks.
\end{abstract}

Keywords: Blood, Gastrointestinal Tract, Moisture Content, Tape Yeast, Visceral Organ

\section{Introduction}

The use of local ingredients in reducing the cost of feed is widely utilized. However, their use for poultry is limited because of a high crude fiber content. This is due to poultry has limitation to digest crude fiber, such as cellulose and hemicelluloses (Yosi et al., 2016). Therefore, it needs a feed processing technology, such as fermentation, to reduce the fiber content and increase the nutrient digestibility. Yeast is a natural ingredient that is widely used as an inoculum in fermentation processes of poultry feedstuff (Khempaka et al., 2014; Sandi et al., 2016; Yosi et al., 2016). In addition, the yeast is also used as a feed supplement in poultry rations that can stimulate the growth process (Yalçın et al., 2013). The use of yeast in the feed has been widely studied and have a significant effect on performance and physiological responses to poultry, such as increasing the immune response (Asli et al., 2007; Yalçın et al., 2010; Haldar et al., 2011), lowering the blood cholesterol levels (Yalçın et al., 2010) and increasing the digestibility of nutrients (Gao et al., 2008).

One type of yeast that could potentially be used is the tape yeast (Yosi et al., 2016). The tape yeast contains Saccharomyces cerevisiae (Bidura et al., 2012), which is able to produce enzymes to digest complex compounds, such as cellulose and hemicellulose and produce simple monosaccharide compounds. It is reported that one affects the growth of $S$. cerevisiae during the fermentation process is the moisture content (Rohmawati et al., 2015). In the process of fermentation solids, moisture content used is in the range $30-80 \%$. If the moisture content is too low, microbial metabolism is inhibited and growth will be disturbed. Conversely, if the moisture content is too high, the porosity of the substrate becomes lower. 
Consequently, aeration and mass transfer processes in the metabolism of microbes are inhibited.

By knowing the optimal moisture content in the fermentation process of locally sourced rations, it is expected that the growth of $S$. cerevisiae to be better so that the nutritional digestibility of the ration is increasing. It is known that the high nutrient digestibility will affect the activity of visceral organs and digestive tract, which can be measured by weight changes (Hetland et al., 2005). In addition, this will also affect the increase of erythrocyte numbers, hemoglobin and hematocrit (Huff et al., 2010), as well as stimulate the immune system to generate more antibodies (Shanmugasundaram et al., 2013). Based on this, further studies to find out the effect of feeding the local ration fermented by tape yeast with different moisture content on bird's performances need to be implemented.

\section{Materials and Methods}

\section{Birds, Feed and Housing}

A total of two hundred of Pegagan ducks aged 3 days was allocated into 5 treatments of experimental fermented rations and kept for 6 weeks. All the ducks were placed in 20 plots $(1 \times \mathrm{w} \times \mathrm{h} ; 1.5 \times 1.2 \times 0.8 \mathrm{~m})$ made of bamboo, with containing 10 ducks per plots. Each plot is equipped with 40 -watt bulb lamp and switched on for $24 \mathrm{~h}$ as a heater until the age of 2 weeks. After 2 weeks, the position of the lights is raised and used only for illumination at night. Rations used is feed by using local raw materials, including refined corn meal, palm kernel cake, coconut pulp, cassava leaf meal, water hyacinth meal, lamtoro leaf meal, kale leaf meal, snail meal, egg shell meal and premix. The composition and nutrient content of the ration can be seen in Table 1 .

\section{Method of Fermentation}

The treatments ration was symbolized as P1, P2, P3, P4 and P5 based on the level of moisture content used in the fermentation process of ration, namely control (without adding water), 40, 50, 60 and $70 \%$. Determination of water content in the ration according to (AOAC, 1995). The fermentation process of ration refers to Bidura et al. (2009) modified. The first stage was the ration was inserted into the container, then added to warm water $\left(50-60^{\circ} \mathrm{C}\right)$ to each ration treatment in accordance with a certain amount. The mixture of feed and water was stirred until uniform, then aerated for 5 min. After that, the tape was inserted into the yeast ration as much as $0.3 \%$ of the weight ration and stirred until blended. The ration was then covered with plastic and stored for $7 \mathrm{~d}$ for aerobic fermentation. After $7 \mathrm{~d}$, the ration is put into the oven at $45^{\circ} \mathrm{C}$ for $6 \mathrm{~h}$. Rations and drinking water are given ad libitum. In this study, tape yeast used is brand "Ragi Tape NKL", which is produced locally and is commonly used in the manufacture of Indonesian food called "Tape".
Table 1. Composition and nutrient content of the experimental ration

\begin{tabular}{lr}
\hline Feed ingredients & \% material $(\mathrm{w} / \mathrm{w})$ \\
\hline Refined corn meal & 57.00 \\
Coconut pulp & 5.00 \\
Palm kernel cake & 4.00 \\
Snail meal & 17.00 \\
Lamtoro leaf meal & 5.00 \\
Cassava leaf meal & 4.00 \\
Water hyacinth meal & 3.00 \\
Kale leaf meal & 4.00 \\
Eggshell meal & 0.50 \\
Premix & 0.50 \\
Total & 100.00 \\
Nutrient content of ration & \\
Crude Protein $(\%)$ & 17.27 \\
Crude Fat $(\%)$ & 7.04 \\
Crude Fiber $(\%)$ & 9.59 \\
ME (kcal $/ \mathrm{kg})$ & 2921.39 \\
Ca $(\%)$ & 0.73 \\
P $(\%)$ & 0.30 \\
Methionine $(\mathrm{g} / 100 \mathrm{~g})$ & 0.21 \\
Lysine $(\mathrm{g} / 100 \mathrm{~g})$ & 0.53 \\
\hline
\end{tabular}

\section{Measurement of the Weights of Visceral Organ and Gastrointestinal Tract}

A total of 10 ducks on each treatment, at the end of the experiment, was randomly selected as many as 2 birds. Ducks were then individually weighed and slaughtered, feathered and eviscerated. The weights of the gizzard, spleen, liver, pancreas, bile and heart were calculated and expressed as a percentage of BW (Rahbar et al., 2011). The empty weight of crop-esophagus, proventriculus, intestinal, duodenum, jejunum, ileum, cecum and rectum parts were recorded. Duodenum was measured from gizzard outlet to the end of the pancreatic loop, jejunum was from the pancreatic loop to Meckel's diverticulum and ileum was from Meckel's diverticulum to the cecal junction. The weight of gastrointestinal tracts parts to slaughtering weight was calculated and expressed as a percentage (Yalçın et al., 2013)

\section{Analysis of Blood Profile and Chemistry}

As many $3 \mathrm{ml}$ of venous blood samples from 2 birds per pen, at the end of experiment, were collected by puncture of the brachial vein using sterilized syringes containing an anticoagulant (Ahmad et al., 2008). Then, the syringes were capped and carried to the laboratory for counting the number of erythrocytes, leukocyte, hemoglobin, hematocrit, Mean Corpuscular Hemoglobin $(\mathrm{MCH})$, Mean Corpuscular Volume (MCV) and Mean Corpuscular Hemoglobin Concentration (MCHC). Blood samples were put into the tubes containing no anticoagulant and then centrifuged at $3.220 \times \mathrm{g}$ for $8 \mathrm{~min}$ at $4^{\circ} \mathrm{C}$. Serum 
was taken and stored at $-20^{\circ} \mathrm{C}$ (Yalçın et al., 2013) for testing of triglyceride, cholesterol, Low-Density Lipoprotein (LDL) and High-Density Lipoprotein (HDL).

\section{Statistical Analysis}

The data were Analyzed with Analysis of Variance (ANOVA) using the SPSS software with version 17. The significance of mean differences among treatments was tested by Duncan's multiple range test at $5 \%$ of a significance level.

\section{Results}

\section{The Weight of Gastrointestinal Tract and Visceral Organ}

Based on Table 2, the treatment significantly $(p<0.05)$ affected the weight of the crop-oesophagus, proventriculus, total of small intestine and ceca, but not significantly $(p>0.05)$ affected the weight of duodenum, jejunum, ileum and rectum. The weight of crop-oesophagus, total of the small intestine and ceca of ducks fed rations fermented with a moisture content of $50 \%$ (P3) was significantly $(\mathrm{p}<0.05)$ the highest among the other treatment ration, namely $1.30,3.09 \%$ and $0.48 \%$, respectively. Meanwhile, the ducks consumed rations fermented with moisture content above $50 \%$ produced the weight of the proventriculus and small intestine that was significantly $(\mathrm{p}<0.05)$ higher than that under $50 \%$. However, the weight of the proventriculus of ducks fed rations fermented with $50-70 \%$ of moisture content was not significantly different $(p>0.05)$, which was 0.78 to $0.81 \%$.

The different water content in fermentation process also significantly affected $(p<0.05)$ the weight of some organs, such as the gizzard and pancreas (Table 3). Moreover, the gizzard and pancreatic weights on ducks fed ration fermented with moisture content above $50 \%$ were significantly $(\mathrm{p}<0.05)$ higher than that under $50 \%$. However, the weight of the bile, liver, spleen and heart in this study was not significantly ( $\mathrm{p}>0.05)$ affected by treatment.

\section{Blood Profile and Chemistry}

Based on Table 4, it can be observed that the treatment significantly $(\mathrm{p}<0.05)$ effected on the number of leukocytes, but the number of erythrocytes, hematocrit, hemoglobin, $\mathrm{MCV}, \mathrm{MCH}$ and $\mathrm{MCHC}$ was not significantly $(p>0.05)$ affected by the treatment. The number of leukocytes in ducks consumed rations fermented with a moisture content of $70 \%$ was significantly $(p<0.05)$ the highest among the other treatment ration, i.e., 35,700 per $\mathrm{mm}^{3}$. Furthermore, the ducks fed rations of fermented with a moisture content of 40 to $60 \%$ had a number of leukocytes, which was not significant $(\mathrm{p}>0.05)$.

The administration of a ration fermented by tape yeast with a different water content had a significant difference $(p<0.05)$ on the level of cholesterol, triglycerides and LDL in the blood of Pegagan ducks, but had not a significant difference $(p>0.05)$ on the HDL levels in the blood (Table 5). Moreover, levels of blood cholesterol and LDL of ducks fed rations fermented with moisture content above 50\% were significantly $(p<0.05)$ lower than that under $50 \%$. If the water level used in fermentation exceeds $50 \%$, the levels of blood cholesterol produced did not differ significantly. The triglyceride level in the blood of ducks fed rations fermented with a water content of $70 \%$ was significantly $(p<0.05)$ the lowest among other treatments, which is $133.75 \mathrm{mg} \mathrm{dL}^{-1}$. The HDL in the duck's blood that was consumed rations fermented with $40-70 \%$ moisture content was relatively equal, i.e. 35.50 to $38 \mathrm{mg} / \mathrm{dl}$.

Table 2. The mean of the weight of the gastrointestinal tract of Pegagan ducks aged 6 weeks

\begin{tabular}{|c|c|c|c|c|c|}
\hline \multirow[b]{2}{*}{ Variable } & \multicolumn{5}{|l|}{ Treatments } \\
\hline & P1 & $\mathrm{P} 2$ & P3 & $\mathrm{P} 4$ & P5 \\
\hline \multicolumn{6}{|l|}{ Gastrointestinal tract (\%): } \\
\hline Crop-oesophagus & $0.93^{\mathrm{a}} \pm 0.08$ & $0.97^{\mathrm{a}} \pm 0.04$ & $1.30^{\mathrm{c}} \pm 0.09$ & $1.10^{\mathrm{b}} \pm 0.08$ & $0.90^{\mathrm{a}} \pm 0.07$ \\
\hline Proventriculus & $0.64^{\mathrm{a}} \pm 0.11$ & $0.61^{\mathrm{a}} \pm 0.05$ & $0.81^{\mathrm{b}} \pm 0.08$ & $0.78^{\mathrm{b}} \pm 0.10$ & $0.81^{\mathrm{b}} \pm 0.08$ \\
\hline Duodenum $^{\text {ns }}$ & $0.43 \pm 0.180$ & $0.40 \pm 0.050$ & $0.60 \pm 0.190$ & $0.48 \pm 0.050$ & $0.50 \pm 0.030$ \\
\hline Jejunum $^{\text {ns }}$ & $0.96 \pm 0.140$ & $1.06 \pm 0.230$ & $1.22 \pm 0.070$ & $1.00 \pm 0.150$ & $1.02 \pm 0.280$ \\
\hline Ileum $^{\text {ns }}$ & $1.00 \pm 0.110$ & $1.03 \pm 0.070$ & $1.28 \pm 0.180$ & $1.14 \pm 0.120$ & $1.15 \pm 0.160$ \\
\hline Total of small intestine & $2.39^{\mathrm{a}} \pm 0.33$ & $2.49^{\mathrm{a}} \pm 0.23$ & $3.09^{\mathrm{b}} \pm 0.28$ & $2.63^{\mathrm{ab}} \pm 0.31$ & $2.68^{\mathrm{ab}} \pm 0.34$ \\
\hline Ceca & $0.35^{\mathrm{a}} \pm 0.03$ & $0.37^{\mathrm{a}} \pm 0.08$ & $0.48^{\mathrm{b}} \pm 0.05$ & $0.32^{\mathrm{a}} \pm 0.060$ & $0.40^{\mathrm{ab}} \pm 0.05$ \\
\hline Rectum $^{\text {ns }}$ & $0.48 \pm 0.07$ & $0.55 \pm 0.060$ & $0.68 \pm 0.260$ & $0.64 \pm 0.1400$ & $0.53 \pm 0.080$ \\
\hline
\end{tabular}

Description: The same superscripts in the same column indicate significantly different $(\mathrm{p}<0.05)$. ns $=$ non significant. P1 $=$ Locally sourced ration fermented without adding water (control). P2, P3, P4 and P5 = locally sourced ration with a moisture content of 40, 50,60 and $70 \%$, respectively 
Table 3. The mean of the weight of visceral organs of Pegagan ducks aged 6 weeks

\section{Treatments}

\begin{tabular}{llllll} 
Variable & P1 & P2 & P3 & P4 & P5 \\
\hline Visceral organs (\%): & & & & & \\
Gizzard & $4.69^{\mathrm{a}} \pm 0.220$ & $5.13^{\mathrm{a}} \pm 0.330$ & $5.78^{\mathrm{b}} \pm 0.35$ & $5.77^{\mathrm{b}} \pm 0.63$ & $5.74^{\mathrm{b}} \pm 0.19$ \\
Bile $^{\mathrm{ns}}$ & $0.34 \pm 0.120$ & $0.35 \pm 0.040$ & $0.34 \pm 0.130$ & $0.33 \pm 0.060$ & $0.351 \pm 0.09$ \\
Liver $^{\text {ns }}$ & $3.66 \pm 0.750$ & $3.26 \pm 0.670$ & $3.78 \pm 0.350$ & $3.63 \pm 0.810$ & $3.61 \pm 0.550$ \\
Pancreas $_{\text {Spleen }}^{\text {ns }}$ & $0.42^{\mathrm{a}} \pm 0.04$ & $0.43^{\mathrm{a}} \pm 0.04$ & $0.57^{\mathrm{b}} \pm 0.07$ & $0.50^{\mathrm{ab}} \pm 0.09$ & $0.56^{\mathrm{b}} \pm 0.04$ \\
Heart $^{\text {ns }}$ & $0.07 \pm 0.04$ & $0.09 \pm 0.02$ & $0.13 \pm 0.07$ & $0.14 \pm 0.070$ & $0.16 \pm 0.040$ \\
\hline Descip & $0.75 \pm 0.06$ & $0.70 \pm 0.09$ & $0.82 \pm 0.12$ & $0.80 \pm 0.110$ & $0.84 \pm 0.050$ \\
\hline
\end{tabular}

Description: The same superscripts in the same column indicate significantly different $(\mathrm{p}<0.05)$. ns $=$ non significant. P1 $=$ Locally sourced ration fermented without adding water (control). P2, P3, P4 and P5 = locally sourced ration with a moisture content of 40, 50,60 and $70 \%$, respectively

Table 4. Mean values of blood profiles of Pegagan ducks aged 6 weeks

\begin{tabular}{|c|c|c|c|c|c|}
\hline \multirow[b]{2}{*}{ Variable } & \multicolumn{5}{|l|}{ Treatments } \\
\hline & P1 & $\mathrm{P} 2$ & P3 & P4 & P5 \\
\hline E erythrocytes $\left(10^{6} / \mathrm{mm}^{3}\right)^{\mathrm{ns}}$ & $2.75 \pm 0.0600$ & $2.60 \pm 0.180$ & $2.50 \pm 0.200$ & $2.53 \pm 0.100$ & $2.68 \pm 0.100$ \\
\hline$\sum$ Leukocytes $\left(10^{3} / \mathrm{mm}^{3}\right)$ & $29.90^{\mathrm{a}} \pm 2.50$ & $29.40^{\mathrm{a}} \pm 2.72$ & $29.80^{\mathrm{a}} \pm 3.02$ & $31.00^{\mathrm{a}} \pm 0.88$ & $35.70^{\mathrm{b}} \pm 0.74$ \\
\hline Hematocrit $(\%)^{\text {ns }}$ & $36.00 \pm 1.410$ & $34.00 \pm 1.830$ & $33.50 \pm 2.520$ & $32.38 \pm 1.970$ & $35.75 \pm 1.000$ \\
\hline Hemoglobin $(\mathrm{g} / \mathrm{dl})^{\mathrm{ns}}$ & $11.35 \pm 0.240$ & $10.93 \pm 0.640$ & $10.70 \pm 0.470$ & $10.64 \pm 0.290$ & $11.40 \pm 0.440$ \\
\hline $\operatorname{MCV}(\mathrm{fl})^{\mathrm{ns}}$ & $130.90 \pm 3.26$ & $130.88 \pm 2.17$ & $134.09 \pm 3.93$ & $128.20 \pm 5.47$ & $133.71 \pm 3.76$ \\
\hline $\mathrm{MCH}(\mathrm{pg})^{\mathrm{ns}}$ & $41.28 \pm 0.870$ & $42.05 \pm 0.500$ & $42.90 \pm 1.710$ & $42.14 \pm 0.520$ & $42.70 \pm 3.100$ \\
\hline $\operatorname{MCHC}(\%)^{\mathrm{ns}}$ & $32.23 \pm 0.220$ & $32.13 \pm 0.180$ & $32.01 \pm 0.280$ & $32.37 \pm 0.590$ & $32.11^{\mathrm{ab}} \pm 2.16$ \\
\hline
\end{tabular}

Description: The same superscripts in the same column indicate significantly different $(\mathrm{p}<0.05)$. ns $=$ non significant. P1 $=$ Locally sourced ration fermented without adding water (control). P2, P3, P4 and P5 = Locally sourced ration with a moisture content of 40 , 50,60 and $70 \%$, respectively

Table 5. Mean values of blood chemistry of Pegagan ducks aged 6 weeks

\begin{tabular}{|c|c|c|c|c|c|}
\hline \multirow[b]{2}{*}{ Variable } & \multicolumn{5}{|l|}{ Treatments } \\
\hline & P1 & P2 & P3 & P4 & P5 \\
\hline Cholesterol (mg/dl) & $146.25^{\mathrm{a}} \pm 2.87$ & $145.25^{\mathrm{a}} \pm 2.87$ & $143.00^{\mathrm{ab}} \pm 2.16$ & $140.50^{b} \pm 3.42$ & $139.75^{b} \pm 0.74$ \\
\hline Triglyceride (mg/dl) & $153.25^{\mathrm{a}} \pm 1.89$ & $152.00^{\mathrm{a}} \pm 6.48$ & $152.25^{\mathrm{a}} \pm 5.12$ & $152.75^{\mathrm{a}} \pm 6.95$ & $133.75^{\mathrm{b}} \pm 4.11$ \\
\hline $\mathrm{LDL}(\mathrm{mg} / \mathrm{dl})$ & $84.75^{\mathrm{a}} \pm 2.870$ & $83.25^{\mathrm{a}} \pm 5.910$ & $76.75^{\mathrm{b}} \pm 2.990$ & $77.25^{\mathrm{b}} \pm 4.350$ & $77.00^{\mathrm{b}} \pm 2.160$ \\
\hline $\mathrm{HDL}(\mathrm{mg} / \mathrm{dl})^{\mathrm{ns}}$ & $38.00 \pm 3.160$ & $36.50 \pm 1.290$ & $35.50 \pm 4.2000$ & $36.75 \pm 2.9900$ & $36.00 \pm 2.1500$ \\
\hline
\end{tabular}

Description: The same superscripts in the same column indicate significantly different $(\mathrm{p}<0.05)$. ns $=$ non significant. P1 $=$ Locally sourced ration fermented without adding water (control). P2, P3, P4 and P5 = locally sourced ration with a moisture content of 40, 50,60 and $70 \%$, respectively

\section{Discussion}

In principle, S. cerevisiae can affect the development of mucosa in the small intestine. $S$. cerevisiae can also promote the development of the small intestine by stimulating the growth of villi (de los Santos et al., 2007), so that ultimately can improve the function of the small intestine (Kidd et al., 2013) and improve the digestibility of nutrients (Akhavan-Salamat et al., 2011). Bradley et al. (1994) reported that supplementation of $S$. cerevisiae in ration caused a change in the morphology and the number of goblet cells in the chicken intestine. In line with this, Santin et al. (2001) also reported that administration of $0.2 \% S$. cerevisiae in the ration could increase the villus height, located in the small intestine mucosa, which is thought to affect the weight of the small intestine. Furthermore, Rahbar et al. (2011) reported that the use of $S$. cerevisiae into the basal diet containing Peganum harmala seed powder significantly influenced the villus height in the jejunum, but no significant effected on the duodenum and ileum.

The gizzard and pancreatic weights of ducks were significantly affected by treatment. The gizzard is a muscular organ that plays a role to reduce the particle size of ingested rations and blends them with several digestive enzymes (Nishii et al., 2015). During the fermentation process, $S$. cerevisiae most likely hydrolyzes the fiber component in the ration into short chains and thus lowers the grinding activity of the gizzard. Hetland et al. (2005) reported that it was difficult to grind coarse insoluble fiber and consequently increased the size of gizzard. It is reasonable to assume that the more gizzard has grinding activity, the more gizzard developed. The same results also occurred in 
pancreatic weight. During the digestion process, $S$. cerevisiae extract might have stimulated the secretion of the pancreatic digestive enzyme, such as $\alpha$-amylase, which is effective in the digestion of dietary starch. This is as reported by Matur et al. (2010) that influence of $S$. cerevisiae extract on pancreatic amylase could be useful in the digestion of dietary starch. Moreover, $\beta$-glucan, known as a component of $S$. cerevisiae, could stimulate cholecystokinin from enteroendocrine cells, where cholecytokinin was effective to stimulate the pancreatic secretion (Chandra and Liddle, 2009; Matur et al., 2010). However, the weight of the bile, liver, spleen and heart in this study was not affected by treatments. The nonsignificant results were also reported by Rahbar et al. (2011) that the weight of the spleen and liver of broilers added to $S$. cerevisiae in the rations were not significantly different.

The high number of leukocytes can be used as an indicator to determine the immune status of poultry. The higher number of immune cells in the blood means that the better the immune system of poultry. Related to the use of $S$. cerevisiae in feed, Savage and Zakrzewska (1996) reported that $S$. cerevisiae had a significant role to stimulate the immune system in the body, which would increase the levels of $\operatorname{IgG}$ and $\mathrm{IgA}$. This has an impact on the improvement of the immune system and can increase poultry antigenic response in the intestinal mucosa (Santin et al., 2001). In line with this, Gao et al. $(2008 ; 2009)$ also stated that chickens consume product fermented by $S$. cerevisiae could improve the lymphocyte cell so that the body immunity was increasing. The same results also reported by Al-Homidan and Fahmy (2007) and El-Husseiny et al., 2008 ) that a product fermented by $S$. cerevisiae might modulate the immune system so that the birds consuming the product could handle the stress better.

The level of cholesterol, triglycerides and LDL in the blood of Pegagan ducks were affected by treatment. The mechanism associated with the cholesterol-lowering effect of yeast could be linked with an inhibitor of 3-hydroxyl-3methylglutaryl- coenzyme reductase (Saleh et al., 2013). In line with this, Paryad and Mahmoudi (2008) reported that dietary supplementation of $1 \% \quad S$. cerevisiae significantly lowered plasma cholesterol and triglyceride concentrations in broiler chickens, while HDL was increased. The results obtained slightly different to that reported by Yalçın et al. (2008) that administration of $S$. cerevisiae in rations added oilseed meal had no effect on cholesterol and blood triglycerides.

\section{Conclusion}

It was concluded that the feeding of locally sourced ration fermented by yeast tape with a moisture content of $50 \%$ provides optimal results to the weight of visceral organs and gastrointestinal tract and also on blood profile and chemistry of Pegagan ducks.

\section{Acknowledgment}

Authors thank to Ministry of Research, Technology and Higher Education who have helped the research funding through the Competence Grant in 2016.

\section{Author's Contributions}

Fitra Yosi: Conducted to the research, analyzed the data and wrote the manuscript.

Sofia Sandi and Miksusanti: Conducted to the research.

\section{Ethics}

All of authors confirm that this article is original and contains unpublished materials and has no ethical issues involved.

\section{References}

Ahmad, T., T. Khalid, T. Mushtaq, M.A. Mirza and A. Nadeem et al., 2008. Effect of potassium chloride supplementation in drinking water on Broiler performance under heat stress conditions. Poult. Sci., 87: 1276-1280. DOI: 10.3382/ps.2007-00299

Akhavan-Salamat, H., H. Ghasemi, A. Khaltabadi-Farahani and M. Kazemi-Bonchenari, 2011. The effects of Saccharomyces cerevisiae on performance and nutrients digestibility in broilers fed with diet containing different levels of phosphorous. African J. Biotechnol., 10: 7526-7533.

Al-Homidan, A. and M.O. Fahmy, 2007. The effect of dried yeast (Saccharomyces cerevisiae) supplementation on growth, performance, carcass chemical analysis, immunity, ileum villi heights and bacterial counts of broiler chickens. Egypt. Poult. Sci. J., 27: 613-623.

AOAC, 1995. Official methods of analysis of AOAC international. AOAC Int., Gaithersburg, MD.

Asli, M.M., S.A. Hosseini, H. Lotfollahian and F. Shariatmadari, 2007. Effect of Probiotics, yeast, vitamin $\mathrm{E}$ and vitamin $\mathrm{C}$ supplements on performance and immune response of laying hen during high environmental temperature. Int. J. Poult. Sci., 6: 895-900. DOI: 10.3923/ijps.2007.895.900

Bidura, I., I. Mahardika, B. Suyadnya, I. Partama and D. Oka et al., 2012. The implementation of Saccharomyces spp.n-2 isolate culture (isolation from traditional yeast culture) for improving feed quality and performance of male Bali ducking. J. Agric. Sci. Res., 2: 486-492.

Bidura, I., D. Warmadewi, D. Candrawati, I. Aryani and I. Utami et al., 2009. The effect of ragi tape fermentation products in diets on nutrients digestibility and growth performance of bali drake. Int. Semin. Anim. Ind. 
Bradley, G.L., T.F. Savage and K.I. Timm, 1994. The effects of supplementing diets with Saccharomyces cerevisiae var. boulardii on male poult performance and ileal morphology. Poult. Sci., 73: 1766-1770. DOI: $10.3382 /$ ps.0731766

Chandra, R. and R.A. Liddle, 2009. Neural and hormonal regulation of pancreatic secretion. Curr. Opin. Gastroenterol., 25: 441-446. DOI: 10.1097/MOG.0b013e32832e9c41

de los Santos, F.S., A.M. Donoghue, M.B. Farnell, G.R. Huff and W.E. Huff et al., 2007. Gastrointestinal maturation is accelerated in turkey poults supplemented with a mannan-oligosaccharide yeast extract (Alphamune). Poult. Sci., 86: 921-930. DOI: $10.1093 / \mathrm{ps} / 86.5 .921$

El-Husseiny, O.M., A.G. Abdallah and K.O. Abdel-Latif, 2008. The Influence of biological feed additives on broiler performance. Int. J. Poult. Sci., 7: 862-871. DOI: $10.3923 /$ ijps.2008.862.871

Gao, J., H.J. Zhang, S.G. Wu, S.H. Yu and I. Yoon et al., 2009. Effect of Saccharomyces cerevisiae fermentation product on immune functions of broilers challenged with Eimeria tenella. Poult. Sci., 88: 2141-2151. DOI: 10.3382/ps.2009-00151

Gao, J., H.J. Zhang, S.H. Yu, S.G. Wu and I. Yoon et al., 2008. Effects of yeast culture in broiler diets on performance and immunomodulatory functions. Poult. Sci., 87: 1377-1384. DOI: 10.3382/ps.2007-00418

Haldar, S., T.K. Ghosh, Toshiwati and M.R. Bedford, 2011. Effects of yeast (Saccharomyces cerevisiae) and yeast protein concentrate on production performance of broiler chickens exposed to heat stress and challenged with Salmonella enteritidis. Anim. Feed Sci. Technol., 168: 61-71. DOI: 10.1016/j.anifeedsci.2011.03.007

Hetland, H., B. Svihus and M. Choct, 2005. Role of insoluble fiber on gizzard activity in layers. J. Applied Poult. Res., 14: 38-46. DOI: 10.1093/japr/14.1.38

Huff, G.R., W.E. Huff, M.B. Farnell, N.C. Rath and F. Solis de los Santos et al., 2010. Bacterial clearance, heterophil function and hematological parameters of transport-stressed turkey poults supplemented with dietary yeast extract. Poult. Sci., 89: 447-456. DOI:10.3382/ps.2009-00328

Khempaka, S., R. Thongkratok, S. Okrathok and W. Molee, 2014. An evaluation of cassava pulp feedstuff fermented with A. oryzae, on growth performance, nutrient digestibility and carcass quality of broilers. J. Poult. Sci., 51: 71-79. DOI: 10.2141/jpsa.0130022

Kidd, M.T., L. Araujo, C. Araujo, C. D. McDaniel and D. McIntyre, 2013. A study assessing hen and progeny performance through dam diet fortification with a Saccharomyces cerevisiae fermentation product. J. Applied Poult. Res., 22: 872-877.

DOI: 10.3382/japr.2013-00774
Matur, E., E. Ergul, I. Akyazi, E. Eraslan and Z.T. Cirakli, 2010. The effects of Saccharomyces cerevisiae extract on the weight of some organs, liver and pancreatic digestive enzyme activity in breeder hens fed diets contaminated with aflatoxins. Poult. Sci., 89: 2213-2220. DOI: $10.3382 /$ ps.2010-00821

Nishii, M., M. Yasutomi and Y. Sone, 2015. Inhibitory effect of whole grain paddy rice feeding on the colonization of Campylobacter jejuni in the cecum of broiler chicks. J. Poult. Sci., 52: 312-317. DOI: $10.2141 /$ jpsa.0140193

Paryad, A. and M. Mahmoudi, 2008. Effect of different levels of supplemental yeast (Saccharomyces cerevisiae) on performance, blood constituents and carcass characteristics of broiler chicks. African J. Agric. Res., 3: 835-842.

Rahbar, M.G., P. Farhoomand and A. Kamyab, 2011. The effect of different concentrations of Peganum harmala seeds with or without a yeast cell wall product on the live performance, intestinal histomorphology and weights of visceral organs of broiler chickens. J. Applied Poult. Res., 20: 454-462. DOI: 10.3382/japr.2010-00261

Rohmawati, D., I. Djunaidi and E. Widodo, 2015. Nutritional values of soybean husk with tape yeast at different levels and incubation times. J. Ternak Trop., 16: 30-33.

Saleh, A.A., K. Hayashi and A. Ohtsuka, 2013. Synergistic effect of feeding Aspergillus awamori and Saccharomyces cerevisiae on growth performance in broiler chickens; promotion of protein metabolism and modification of fatty acid profile in the muscle. J. Poult. Sci., 50: 242-250.

Sandi, S., F. Yosi and M. Miksusanti, 2016. Performance and protein efficiency ratio of starter phase pegagan ducks fed fermented rations made from locally sourced materials. Pakistan J. Nutr., 15: 268-273. DOI: $10.3923 /$ pjn.2016.268.273

Santin, E., A. Maiorka, M. Macari, M. Grecco and J.C. Sanchez et al., 2001. Performance and intestinal mucosa development of broiler chickens fed diets containing Saccharomyces cerevisiae cell wall. J. Applied Poult. Res., 10: 236-244. DOI: $10.1093 /$ japr/10.3.236

Savage, T. and E. Zakrzewska, 1996. The performance of male turkeys fed a starter diet containing a mannanoligosaccharide (Bio-Mos) from day old to eight weeks of age. Proceedings of the Alltech's 12th Annual Symposium Biotechnology in the Feed Industry, (BFI' 96), pp: 47-54.

Shanmugasundaram, R., M. Sifri and R.K. Selvaraj, 2013. Effect of yeast cell product (CitriStim) supplementation on broiler performance and intestinal immune cell parameters during an experimental coccidial infection1. Poult. Sci., 92: 358-363. DOI: 10.3382/ps.2012-02776 
Yalçın, S., H. Eser, S. Yalçın, S. Cengiz and O. Eltan, 2013. Effects of dietary yeast autolysate (Saccharomyces cerevisiae) on performance, carcass and gut characteristics, blood profile and antibody production to sheep red blood cells in broilers. J. Applied Poult. Res., 22: 55-61. DOI: 10.3382/japr.2012-00577

Yalçın, S., B. Ozsoy, H. Erol and S. Yalçın, 2008. Yeast culture supplementation to laying hen diets containing soybean meal or sunflower seed meal and its effect on performance, egg quality traits and blood chemistry. J. Applied Poult. Res., 17: 229236. DOI: $10.3382 /$ japr.2007-00064
Yalçın, S., S. Yalçın, K. Çakın, Ö. Eltan and L. Dağaşan, 2010. Effects of dietary yeast autolysate (Saccharomyces cerevisiae) on performance, egg traits, egg cholesterol content, egg yolk fatty acid composition and humoral immune response of laying hens. J. Sci. Food Agric., 90: 1695-1701. DOI: $10.1002 /$ jsfa.4004

Yosi, F., S. Sandi, Miksusanti, N. Rofiq and Sutejo, 2016. Nutrient digestibility in pegagan ducks fed diet containing locally sourced ingredients fermented with yeast inoculum. Int. J. Poult. Sci., 15: 103-110. DOI: 10.3923/ijps.2016.103.110 